\title{
Distribution and Seasonal Population Dynamics of Phytophthora citrophthora and P. parasitica in Arizona Citrus Orchards and Effect of Fungicides on Tree Health
}

\author{
M. E. Matheron, Extension Plant Pathologist, and M. Porchas and J. C. Matejka, Research Specialists, Univer- \\ sity of Arizona, Yuma Agricultural Center, Yuma 85364
}

\begin{abstract}
Matheron, M. E., Porchas, M., and Matejka, J. C. 1997. Distribution and seasonal population dynamics of Phytophthora citrophthora and P. parasitica in Arizona citrus orchards and effect of fungicides on tree health. Plant Dis. 81:1384-1390.

The distribution and seasonal population dynamics of Phytophthora citrophthora and P. parasitica within citrus orchards in southwestern and central Arizona were determined over a multiple-year period. In central Arizona, P. citrophthora alone, $P$. parasitica alone, or both pathogens together were recovered from 7,37 , and $41 \%$ of sampled orchards, respectively, whereas in the southwestern production area, the same pathogens alone or in combination were recovered from 17,50 , and $17 \%$ of sampled orchards, respectively. For a 6-year period, the average population density of $P$. parasitica in southwestern Arizona was 16.7 propagules/g of dry soil. For 2 of 3 years, the population density of $P$. citrophthora at the 10 -cm soil depth was significantly higher in the spring than in the preceding winter or the following autumn season. There were no significant seasonal multiple-year differences in population levels of $P$. parasitica. Propagule densities of both pathogens, as well as root densities, generally decreased as soil depth increased from 10 to $60 \mathrm{~cm}$. No consistent significant correlation was detected between propagule density of either pathogen and soil temperature or soil moisture at the time of collection. A multipleyear treatment program with fosetyl-Al or metalaxyl resulted in significantly healthier tree canopies and higher root densities compared to nontreated trees; however, population densities of $P$. citrophthora and $P$. parasitica did not differ significantly when nontreated trees were compared to those receiving fungicide treatments.
\end{abstract}

Phytophthora gummosis and root rot are among the most important fungal diseases of citrus (11). In the United States, Phytophthora citrophthora and P. parasitica are both cited as causal agents of gummosis and root rot; however, $P$. parasitica is the primary pathogen in Florida (31) and Texas $(27,28)$, while both $P$. citrophthora and $P$. parasitica are major causes of disease in California $(5,12)$. Losses attributable to Phytophthora gummosis and root rot have been reduced through the use of the systemic fungicides fosetyl-Al (Aliette, Rhone-Poulenc Ag Co., Research Triangle Park, NC) and metalaxyl (Ridomil, Novartis Crop Protection, Greensboro, NC; $2,4,23,25,29)$. A single application of either fungicide can provide maximum protection from colonization by $P$. citrophthora and $P$. parasitica for at least 3 months (16).

To gain maximum biological, economic, and environmental benefits from fosetyl-Al

Corresponding author: M. E. Matheron

E-mail: matheron@ag.arizona.edu

This research was supported by the Arizona Citrus Research Council, as well as by state and Hatch funds allocated to the Arizona Agricultural Experiment Station.

Accepted for publication 18 August 1997.

Publication no. D-1997-0929-04R

(C) 1997 The American Phytopathological Society or metalaxyl, a treatment program should be initiated only when significant disease development is likely to occur. The population density of Phytophthora spp. in an orchard is a potential indicator of the probability of significant disease development. Threshold values for soil populations of $P$. citrophthora or $P$. parasitica have not been established definitively; however, researchers have suggested that orchards with mean densities of less than 10 propagules of $P$. parasitica $/ \mathrm{cm}^{3}$ of soil likely cannot be treated economically with fosetyl-Al or metalaxyl, whereas a population of the same pathogen in the range of 15 to 20 propagules/g of rhizosphere soil can reduce citrus yield by $20 \%(22,30)$. A concern regarding determination of population levels of Phytophthora spp. in soil is the time of year when sampling should be performed. In California (6) and Italy (8), high levels of $P$. parasitica were detected in citrus orchard soils in the summer and early autumn, whereas very low levels of the pathogen were observed during the winter. On the other hand, propagule densities of $P$. parasitica in Florida (33) were not related to time of year when samples were collected.

The goals of our research studies were (i) to determine the relative distribution of $P$. citrophthora and $P$. parasitica within citrus orchards in Arizona; (ii) to examine the degree of variability within yearly measurements of population density of $P$. parasitica within one citrus production district; (iii) to search for possible seasonal changes in populations of $P$. citrophthora and $P$. parasitica at soil depths of 10,30 , and $60 \mathrm{~cm}$, and to determine potential relationships to root density and soil temperature at these depths; and (iv) to evaluate the effect of multiple-year applications of fosetyl-Al or metalaxyl on the health of a citrus tree orchard grown under the arid environmental growing conditions of the desert southwest. A partial account of this research was reported earlier (18).

\section{MATERIALS AND METHODS}

Distribution of Phytophthora spp. within citrus orchards. From 1985 to 1989, 334 soil samples were collected from 79 citrus orchards in Yuma County in southwestern Arizona and Maricopa County in the central part of the state. The majority of orchards sampled in Yuma and Maricopa Counties were lemon (Citrus limon) and navel orange (C. sinensis) plantings, respectively, although Valencia oranges and grapefruit ( $C$. paradisi) were occasionally sampled in both counties. Several different rootstocks were used in these commercial orchards, including rough lemon (C. jambhiri), sour orange ( $C$. aurantium), volkamer lemon $(C$. volkameriana), alemow (C. macrophylla), Troyer citrange $(C$. sinensis $\times$ Poncirus trifoliata), and Cleopatra mandarin $(C$. reshni). Each soil sample was tested for the presence of $P$. citrophthora or $P$. parasitica by utilizing a previously published technique (21). Soil and associated feeder roots were collected with a shovel at a depth of 5 to $30 \mathrm{~cm}$ from three locations within the drip line of each citrus tree. These three samples were thoroughly mixed, then 500 $\mathrm{cm}^{3}$ of this combined soil sample was placed into a plastic bag and maintained at 21 to $25^{\circ} \mathrm{C}$ during transport to the laboratory and in storage prior to processing. Samples were processed within $24 \mathrm{~h}$ of collection.

In the laboratory, the soil was placed into a container, then 2 ripe but green-colored, unblemished Bartlett or Anjou pear fruits were placed on the surface of the soil. Sufficient water was added to establish a 1- to 2-cm layer of free water at the soil surface. After incubation at $24^{\circ} \mathrm{C}$ for $48 \mathrm{~h}$, the fruits were removed from the soil, washed in water, and incubated for an additional 24 to $72 \mathrm{~h}$ at $24^{\circ} \mathrm{C}$. Firm brown spots developed on pear fruits invaded by Phytophthora spp. Small pieces of tissue from the advancing margin of 10 different 
brown spots per soil sample were placed on pimaricin ampicillin rifampicin pentachloronitrobenzene (PARP) medium (9) and observed for growth of Phytophthora spp. Morphological growth characteristics on PARP medium were used to distinguish between $P$. citrophthora and $P$. parasitica. This was a qualitative determination of the distribution of $P$. citrophthora and $P$. parasitica within citrus plantings in Arizona.

From 1990 to 1995, the population density of $P$. parasitica was determined for 765 soil samples collected from citrus orchards in the Yuma Mesa region of Yuma County. Samples were collected under the canopy of subject trees in the same manner and maintained within the same temperature range until processing as described earlier. Samples were processed within 24 $\mathrm{h}$ of collection. Soil samples were collected primarily from March through November.

The population density of $P$. parasitica in each soil sample was estimated using a modification of procedures previously employed $(6,10,32,35)$. Two 10 -g subsamples of soil (dry weight basis), from which roots and rocks were removed, were weighed out for each field sample. Each subsample was placed into a 250 -ml flask. Water was added to each flask to produce $100 \mathrm{ml}$ of soil suspension. The flask was swirled rapidly until the soil was evenly mixed within the suspension. Five $\mathrm{ml}$ of the suspension was drawn into a 10-ml wide-mouth pipette, and 1-ml aliquots were placed onto the bottom of each of five 100 - by $15-\mathrm{mm}$ plastic petri dishes. Ten ml of PVPH (34) selective medium was dispensed immediately over the soil slurry in each petri dish, and the dish was swirled to distribute the slurry throughout the media. After 4 days of incubation in darkness at $28^{\circ} \mathrm{C}$, each colony of Phytophthora spp. appearing on soil dilution plates was subcultured onto PARP medium to aid in the morphological identification of $P$. parasitica. The population density of $P$. parasitica was calculated as propagules/g of soil.

Populations of $P$. citrophthora, $P$. parasitica, and root densities. Two commercial citrus orchards were sampled monthly during this study; (i) a Valencia orange planting on rough lemon rootstock established in 1970 in Yuma County on Superstition sand (a deep sandy soil of moderate alkalinity containing some fine white lime masses); and (ii) a navel orange orchard on Troyer citrange rootstock established in 1975 in Maricopa County on a Mohall loam soil (a deep soil of moderate alkalinity with large concentrations of lime below $66 \mathrm{~cm}$ ). At each location, five groups of 3 trees were used for pathogen population studies. Each month, beginning September 1991, soil cores $9 \mathrm{~cm}$ in diameter were collected from the same five groups of 3 trees in Yuma and Maricopa Counties with a bucket auger at a depth of 10, 30, and 60 $\mathrm{cm}$ from a location not previously sampled within the drip line of each tree. The individual soil samples at each depth from each of the 3 trees in a sampling group were combined and thoroughly mixed. A $500-\mathrm{cm}^{3}$ volume of soil from this combined sample was placed in a plastic bag and transported back to the laboratory. Therefore, each month for 24 and 36 consecutive months in Yuma and Maricopa Counties, respectively, five soil samples from depths of 10, 30, and $60 \mathrm{~cm}$ were collected from each orchard site. Soil samples routinely were collected from 4 to 20 days (average 9 days) after a significant rainfall or flood irrigation of the Yuma County orchard, or furrow irrigation of the Maricopa County orchard.

Populations of $P$. citrophthora and $P$. parasitica were estimated using procedures described earlier. Total dry weight of rootlets less than $2 \mathrm{~mm}$ in diameter within each soil sample was determined by placing root material from each soil sample into a 50$\mathrm{ml}$ beaker, drying for $24 \mathrm{~h}$ at $60^{\circ} \mathrm{C}$, then recording the $\mathrm{mg}$ of dry root weight $/ \mathrm{cm}^{3}$ of

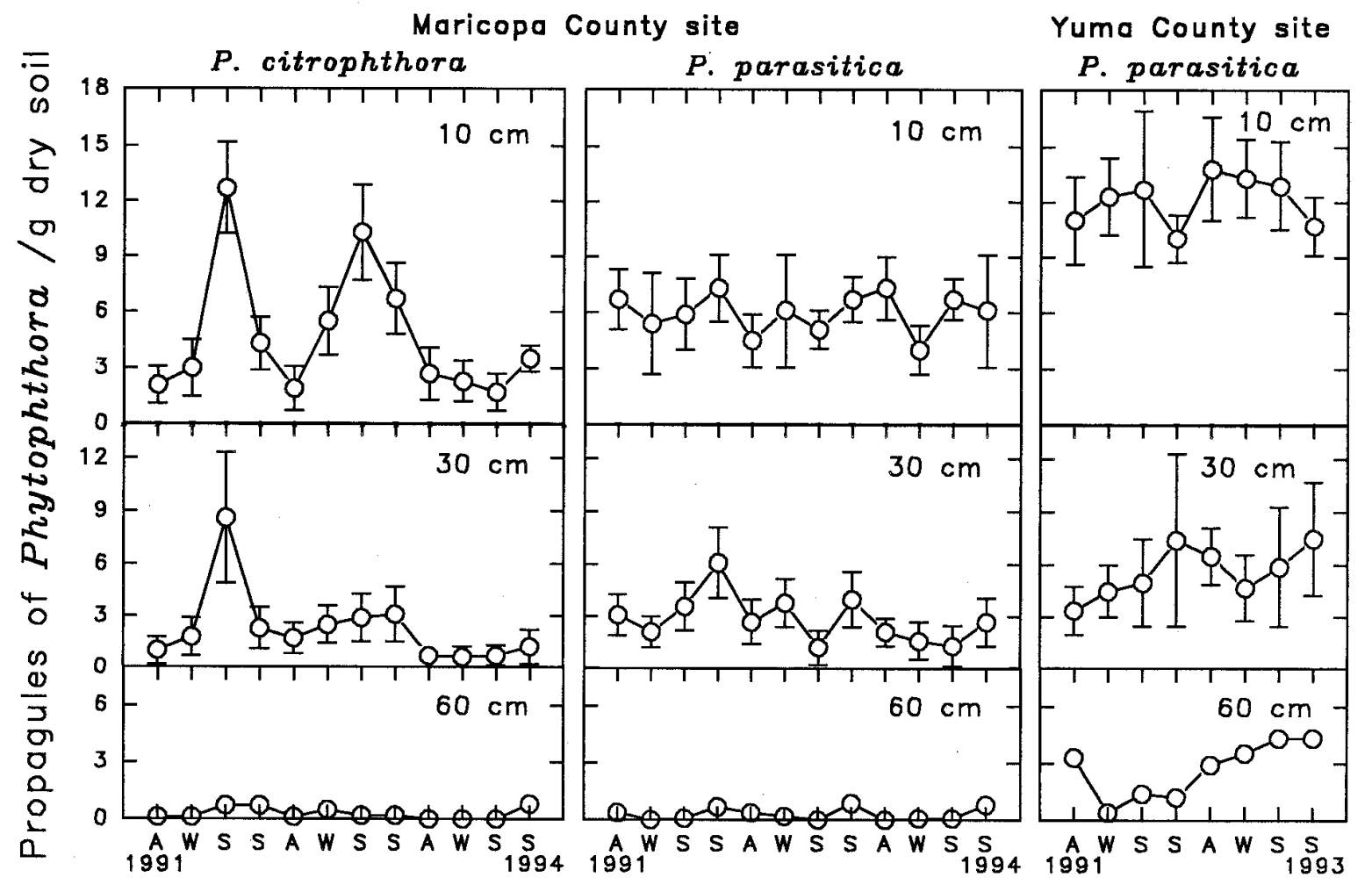

Season

Fig. 1. Seasonal population levels of Phytophthora citrophthora and P. parasitica at soil depths of 10,30 , and $60 \mathrm{~cm}$ within a navel orange orchard on Troyer citrange rootstock established in 1975 in Maricopa County, and levels of $P$. parasitica at the same soil depths within a Valencia orange orchard on rough lemon rootstock established in 1970 in Yuma County. Each data point represents 3 monthly values, where Autumn = September, October, November; Winter = December, January, February; Spring = March, April, May; and Summer = June, July, August. Soil samples were collected from September 1991 to August 1994 in Maricopa County, and from September 1991 to August 1993 in Yuma County. Error bars represent $95 \%$ confidence intervals. 
soil. Soil moisture was determined gravimetrically for soil samples collected.

For the duration of this study, hourly soil temperatures were recorded under the tree canopy where soil samples were collected, using thermistor probes (Ryan Instruments, Redmond, WA) buried in soil at 10, 30, and $60 \mathrm{~cm}$.

Effect of fungicides on tree health. A 30-year-old navel orange orchard on rough lemon rootstock established in 1958 near Waddell in central Arizona was used for this study. In a randomized complete block experimental design, 5 replicate trees in each of four blocks for a total of 20 trees were either (i) not treated with any fungicide (nontreated control), (ii) treated with foliar applications of fosetyl-Al (Aliette $80 \mathrm{WP}$ at a rate of $5.6 \mathrm{~kg}$ of product per ha), or (iii) treated with soil applications of metalaxyl (Ridomil 2E at a rate of $30 \mathrm{ml}$ of product per tree). Experimental trees and tree rows were separated by nontreated trees and tree rows. Fungicides were applied 8 June 1988; 26 March and 27 July 1989; 23 March, 29 May, and 31 July 1990; 22 April, 17 June, and 26 September 1991; and 27 April, 30 June, and 30 September 1992.

General tree health was assessed in 1988 (at the beginning of this study), 1991, and 1992 by rating the tree canopy according to the following scale: 1 = healthy tree; $2=$ some decline; $3=$ moderate decline; $4=$ severe decline; $5=$ dead tree. Soil and associated feeder roots were collected with a bucket auger $9 \mathrm{~cm}$ in diameter at a depth of 2 to $10 \mathrm{~cm}$ from three locations within the drip line of each citrus tree. Soil samples were combined and mixed, then 500 $\mathrm{cm}^{3}$ of this combined sample was placed into a plastic bag and maintained at 21 to $25^{\circ} \mathrm{C}$ during transport to the laboratory and in storage prior to processing.

Populations of $P$. citrophthora and $P$. parasitica, as well as total dry weight of rootlets less than $2 \mathrm{~mm}$ in diameter, within each soil sample were determined using procedures described earlier.

Statistical treatment of data. Error bars in Figure 1 represent 95\% confidence intervals. Means with nonoverlapping $95 \%$ confidence intervals were considered significantly different (7). For comparisons of pathogen propagule densities and root densities at different soil depths, a one way repeated measures analysis of variance (ANOVA) was used to demonstrate significance when data fit a normal distribution and variances were homogeneous, whereas the nonparametric Friedman repeated measures ANOVA on ranks was used when data failed tests for normality or homogeneous variances. When ANOVA indicated significant differences, pairwise multiple comparisons of means was accomplished with the Student-NewmanKeuls test $(P<0.05)$. Linear regression was used to determine possible significant

Table 1. Distribution of Phytophthora citrophthora (P. cit.) and P. parasitica (P. par.) within citrus orchards in Maricopa and Yuma Counties in Arizona ${ }^{\mathrm{z}}$

\begin{tabular}{|c|c|c|c|c|c|c|c|c|}
\hline \multirow[b]{2}{*}{ Location } & \multirow[b]{2}{*}{ Samples (no.) } & \multicolumn{3}{|c|}{ Samples (\%) } & \multirow[b]{2}{*}{ \# of Orchards } & \multicolumn{3}{|c|}{ Orchards $(\%)$} \\
\hline & & P. cit. only & P. par. only & Both fungi & & P. cit. only & P. par. only & Both fungi \\
\hline Maricopa West & 78 & 24 & 36 & 10 & 18 & 6 & 39 & 39 \\
\hline Maricopa East & 36 & 19 & 47 & 37 & 9 & 11 & 33 & 44 \\
\hline Maricopa County totals & 114 & 23 & 39 & 13 & 27 & 7 & 37 & 41 \\
\hline Yuma Valley & 52 & 27 & 13 & 2 & 17 & 41 & 12 & 6 \\
\hline Yuma Mesa & 144 & 6 & 52 & 5 & 27 & 7 & 67 & 26 \\
\hline Yuma East & 24 & 0 & 67 & 8 & 8 & 0 & 75 & 12 \\
\hline Yuma County totals & 220 & 10 & 51 & 4 & 52 & 17 & 50 & 17 \\
\hline
\end{tabular}

${ }^{\mathrm{z}}$ Values presented summarize results from soil samples collected from November 1985 through July 1989.

Table 2. Average population density of Phytophthora parasitica and percentage of samples within certain population ranges from soil samples collected from the Yuma Mesa citrus production region during 1990-1995

\begin{tabular}{|c|c|c|c|c|c|c|}
\hline \multirow[b]{2}{*}{ Year } & \multirow[b]{2}{*}{ Total samples } & \multirow[b]{2}{*}{ Propagules of $P$. parasitica ${ }^{\mathrm{Z}}$} & \multicolumn{4}{|c|}{ Samples containing the following populations $\mathrm{z}^{\mathrm{z}}$ of $P$. parasitica $(\%)$} \\
\hline & & & 0 & $1-10$ & $11-20$ & $>20$ \\
\hline 1990 & 135 & 8.6 & 40 & 39 & 11 & 10 \\
\hline 1991 & 60 & 10.9 & 35 & 40 & 10 & 15 \\
\hline 1992 & 137 & 21.0 & 11 & 33 & 27 & 29 \\
\hline 1993 & 176 & 21.6 & 17 & 30 & 16 & 37 \\
\hline 1994 & 149 & 21.9 & 21 & 40 & 19 & 20 \\
\hline 1995 & 108 & 16.1 & 15 & 40 & 26 & 19 \\
\hline $1990-1995$ & 765 & 16.7 & 22 & 36 & 20 & 22 \\
\hline
\end{tabular}

${ }^{\mathrm{z}}$ Propagules of the pathogen/g of dry soil.

Table 3. Comparison of yearly population densities of Phytophthora citrophthora and P. parasitica and root densities of navel orange trees on Troyer citrange rootstock at soil depths of 10,30 , and $60 \mathrm{~cm}^{\mathrm{x}}$

\begin{tabular}{|c|c|c|c|c|c|}
\hline & \multirow[b]{2}{*}{ Soil depth $(\mathbf{c m})$} & \multicolumn{4}{|c|}{ Time period $\left(\right.$ years) ${ }^{y}$} \\
\hline & & 1991-92 & $1992-93$ & 1993-94 & 1991-94 \\
\hline Propagules of $P$. citrophthora per $\mathrm{g}$ of dry soil ${ }^{\mathrm{Z}}$ & $\begin{array}{l}10 \\
30 \\
60\end{array}$ & $\begin{array}{l}5.4 \mathrm{a} \\
3.2 \mathrm{a} \\
0.3 \mathrm{~b}\end{array}$ & $\begin{array}{l}6.0 \mathrm{a} \\
2.6 \mathrm{~b} \\
0.3 \mathrm{c}\end{array}$ & $\begin{array}{l}2.8 \mathrm{a} \\
0.9 \mathrm{~b} \\
0.2 \mathrm{~b}\end{array}$ & $\begin{array}{l}4.8 \mathrm{a} \\
2.2 \mathrm{~b} \\
0.3 \mathrm{c}\end{array}$ \\
\hline Propagules of $P$. parasitica per $\mathrm{g}$ of dry soil & $\begin{array}{l}10 \\
30 \\
60\end{array}$ & $\begin{array}{l}5.6 \mathrm{a} \\
3.1 \mathrm{~b} \\
0.2 \mathrm{c}\end{array}$ & $\begin{array}{l}6.2 \mathrm{a} \\
3.2 \mathrm{~b} \\
0.3 \mathrm{c}\end{array}$ & $\begin{array}{l}6.3 \mathrm{a} \\
2.4 \mathrm{~b} \\
0.3 \mathrm{c}\end{array}$ & $\begin{array}{l}6.0 \mathrm{a} \\
2.9 \mathrm{~b} \\
0.3 \mathrm{c}\end{array}$ \\
\hline Root density (mg dry wt $/ \mathrm{cm}^{3}$ of soil) & $\begin{array}{l}10 \\
30 \\
60\end{array}$ & $\begin{array}{l}0.60 \mathrm{a} \\
0.19 \mathrm{~b} \\
0.08 \mathrm{~b}\end{array}$ & $\begin{array}{l}0.80 \mathrm{a} \\
0.20 \mathrm{~b} \\
0.03 \mathrm{~b}\end{array}$ & $\begin{array}{l}0.70 \mathrm{a} \\
0.06 \mathrm{~b} \\
0.01 \mathrm{~b}\end{array}$ & $\begin{array}{l}0.70 \mathrm{a} \\
0.16 \mathrm{~b} \\
0.04 \mathrm{c}\end{array}$ \\
\hline
\end{tabular}

$\overline{\mathrm{x}}$ Values for propagules of each pathogen or root density in each column followed by a different letter are significantly different $(P<0.05)$ according to the Student-Newman-Keuls test.

y Each value for 1991-92, 1992-93, and 1993-94 was derived from 12 consecutive monthly samples collected from September to August.

${ }^{\mathrm{z}}$ One g of dry Mohall loam soil is equivalent to $0.77 \mathrm{~cm}^{3}$. 
relationships between soil temperature or soil moisture and population densities of $P$. citrophthora and P. parasitica.

Data from the study evaluating the effects of fungicides on tree health were analyzed by one-way ANOVA when data were normally distributed and variances were homogeneous, whereas the nonparametric Kruskal-Wallis one-way ANOVA on ranks was used when appropriate. Student's $t$ test was used to seek potential significant differences in propagule densities of $P$. citrophthora or $P$. parasitica when values for April 1992 were compared to those recorded in November 1992.

\section{RESULTS}

Distribution of Phytophthora spp. within citrus orchards. From 334 soil samples collected in Arizona during 1985 to 1989 , Phytophthora spp. were recovered from $85 \%$ of the 79 citrus orchards sampled in Maricopa and Yuma Counties (Table 1). In Maricopa County, $P$. citrophthora alone, $P$. parasitica alone, or both pathogens in combination were recovered from 7,37 , and $41 \%$ of sampled orchards, respectively, whereas in Yuma County, the same pathogens either alone or in combination were recovered from 17 , 50 , or $17 \%$ of sampled orchards, respectively.

The number of samples collected from a particular orchard ranged from 3 to 8 . In all cases, each tested soil sample represented a single tree within an orchard. The majority of soil samples contained only $P$. citrophthora or $P$. parasitica, with only 4 and $13 \%$ of samples containing both pathogens in Yuma and Maricopa Counties, respectively.

From 1990 to 1995, the average population density of $P$. parasitica detected in soil samples collected from the Yuma Mesa region of Yuma County ranged from a low in 1990 of 8.6 to a high of 21.9 propagules/g of dry soil in 1994, with a 6-year average value of 16.7 (Table 2). The percentage of soil samples from which no Phytophthora spp. were recovered ranged from 11 to $40 \%$, with a 6-year average value of $22 \%$ (Table 2). The percentage of soil samples containing at least 11 propagules of $P$. parasitica/g of dry soil ranged from a low of $21 \%$ in 1990 to a high of $56 \%$ in 1992 . A majority of the soil samples collected each year from the Yuma Mesa region were from orchards sampled in previous years.

Populations of $P$. citrophthora, $P$. parasitica, and root densities. The navel orange orchard on Troyer citrange rootstock in Maricopa County contained both $P$. citrophthora and P. parasitica, whereas the Valencia orange orchard on rough lemon rootstock in Yuma County contained only $P$. parasitica. For 2 of 3 years at the $10-\mathrm{cm}$ depth and for 1 of 3 years at the $30-\mathrm{cm}$ depth, the population density of $P$. citrophthora in the Maricopa County orchard was significantly higher in the spring (March through May) than in the preceding winter (December through February) or the following autumn (September through November; Fig. 1). In contrast, at the same soil depths, there were no significant multiple-year seasonal differences in population levels of $P$. parasitica within the same orchard in Maricopa County or the planting in Yuma County. However, the population density of $P$. parasitica in the Maricopa County orchard at the $10-\mathrm{cm}$ soil depth was significantly lower in the winter of 1993 to 94 than during the preceding autumn or following spring. The population level of $P$. citrophthora in the Maricopa County orchard tended to decrease, sometimes significantly, as soil depth increased from 10 to $30 \mathrm{~cm}$ and from 30 to $60 \mathrm{~cm}$ for each of the 3 years that monthly soil propagule densities were determined (Table 3). For the cumulative 3-year period, the population density of $P$. citrophthora decreased significantly as the soil depth increased from 10 to $30 \mathrm{~cm}$ and from 30 to $60 \mathrm{~cm}$. Levels of $P$. parasitica in the same orchard decreased significantly as soil depth increased for each individual year of the study, as well as for the entire 3 -year period. In the Yuma County orchard, propagule densities tended to decrease with increasing soil depth in each year, and decreased significantly for the 2year sampling period at this location as soil depth increased from 10 to $30 \mathrm{~cm}$ and from 30 to $60 \mathrm{~cm}$ (Table 4).

Root density in the Maricopa County orchard tended to decrease, sometimes sig- nificantly, as soil depth increased from 10 to $30 \mathrm{~cm}$ and from 30 to $60 \mathrm{~cm}$ in each of the 3 years when data were collected; however, all these differences were significant when the entire 3-year data set was combined and analyzed (Table 3). In the Yuma County orchard, root density for the entire 2-year sampling period decreased significantly as soil depth increased from 10 to $30 \mathrm{~cm}$; however, there was no significant difference in the amount of feeder roots at the 30- and 60-cm depths (Table 4).

The monthly range of soil temperatures and their average value for 1992 recorded at depths of 10,30, and $60 \mathrm{~cm}$ in the Maricopa County and Yuma County orchards are presented in Figure 2. The temperatures recorded in 1991, 1993, and 1994 at the Maricopa County site, and in 1991 and 1993 at the Yuma County site, were similar to values presented for 1992. The monthly range in temperature at all 3 soil depths in Maricopa County tended to be larger than the monthly range in temperature recorded at the Yuma County site. The average daily temperature range in the Maricopa County orchard at soil depths of 10,30 , and $60 \mathrm{~cm}$ was $5.4,1.1$, and $0.4^{\circ} \mathrm{C}$, respectively, whereas the average daily temperature range in the Yuma County orchard at the same soil depths was $2.5,0.7$, and $0.4^{\circ} \mathrm{C}$, respectively.

Soil moisture at the time of sample collection at depths of 10,30 , and $60 \mathrm{~cm}$ in the Maricopa County orchard on Mohall loam ranged from 8 to $24 \%$ throughout the 3 -year duration of this study, whereas values for the Yuma County planting on Superstition sand ranged from 8 to $10 \%$ for the 2-year period of sample collection at this site. One g dry loam soil from the Maricopa orchard, and $1 \mathrm{~g}$ dry sandy soil from the Yuma orchard, was equivalent to 0.77 and $0.66 \mathrm{~cm}^{3}$, respectively. For the regression analysis of propagule densities of $P$. citrophthora or $P$. parasitica with soil moisture in the Maricopa County orchard at sampling depths of 10,30 , and $60 \mathrm{~cm}$, no significant relationships were detected ( $P$ ranged from 0.291 to 0.910 and coefficients of determination $\left[\mathrm{R}^{2}\right]$ ranged from 0.000 to 0.035 ). Additionally, there was no significant relationship between propagules of $P$. citrophthora and soil temperature at

Table 4. Comparison of yearly population densities of Phytophthora parasitica and root densities of Valencia orange trees on rough lemon rootstock at soil depths of 10,30 , and $60 \mathrm{~cm}^{\mathrm{x}}$

\begin{tabular}{|c|c|c|c|c|}
\hline & \multirow[b]{2}{*}{ Soil depth (cm) } & \multicolumn{3}{|c|}{ Time period (years) ${ }^{y}$} \\
\hline & & 1991-92 & $1992-93$ & $1991-93$ \\
\hline Propagules of $P$. parasitica per $\mathrm{g}$ of dry soil $\mathrm{I}^{\mathrm{z}}$ & $\begin{array}{l}10 \\
30 \\
60\end{array}$ & $\begin{array}{r}11.7 \mathrm{a} \\
5.1 \mathrm{~b} \\
1.6 \mathrm{c}\end{array}$ & $\begin{array}{r}12.7 \mathrm{a} \\
6.1 \mathrm{~b} \\
3.8 \mathrm{~b}\end{array}$ & $\begin{array}{r}12.2 \mathrm{a} \\
5.6 \mathrm{~b} \\
2.7 \mathrm{c}\end{array}$ \\
\hline Root density (mg dry wt $/ \mathrm{cm}^{3}$ of soil). & $\begin{array}{l}10 \\
30 \\
60\end{array}$ & $\begin{array}{l}0.20 \mathrm{a} \\
0.16 \mathrm{a} \\
0.20 \mathrm{a}\end{array}$ & $\begin{array}{l}0.30 \mathrm{a} \\
0.11 \mathrm{~b} \\
0.13 \mathrm{~b}\end{array}$ & $\begin{array}{l}0.30 \mathrm{a} \\
0.13 \mathrm{~b} \\
0.17 \mathrm{~b}\end{array}$ \\
\hline
\end{tabular}

$\overline{\mathrm{x}}$ Values for propagules of $P$. parasitica or root density in each column followed by a different letter are significantly different $(P<0.05)$ according to the Student-Newman-Keuls test.

y Each value for 1991-92 and 1992-93 was derived from 12 consecutive monthly samples collected from September to August.

${ }^{\mathrm{z}}$ One g of dry Superstition sand soil is equivalent to $0.66 \mathrm{~cm}^{3}$. 
the time of collection in Maricopa County ( $P$ and $\mathrm{R}^{2}$ ranged from 0.226 to 0.999 and from 0.000 to 0.043 , respectively); however, propagules of $P$. parasitica at the 30and 60-cm depth (but not the 10-cm depth) increased as soil temperature increased $(P$ $=0.006$ and $<0.001$ for each depth, respectively). For the Yuma County orchard, no significant relationship between propagule densities of $P$. parasitica and soil moisture or soil temperature at the time of collection were observed $\left(P\right.$ and $\mathrm{R}^{2}$ values ranged from 0.110 to 0.740 and from 0.005 to 0.117 , respectively).

Effect of fungicides on tree health. The rating of canopy health was not significantly different among any of the treatments at the onset of this study; how- ever, 3 and 4 years later, trees receiving treatments of fosetyl-Al or metalaxyl had significantly healthier canopies compared to untreated trees (Table 5). Population densities of $P$. citrophthora and $P$. parasitica varied between sampling dates and treatments, but no statistically significant differences attributable to the different treatments were detected. The population density of $P$. citrophthora recorded for all trees in the study was 3.5 and 0.1 propagules per $g$ dry soil in April and November 1992, respectively, levels that were significantly different. The population density of $P$. parasitica from the same samples was 6.3 and 4.1 propagules per $g$ dry soil, values that did not differ significantly. In April and November 1992, root densities

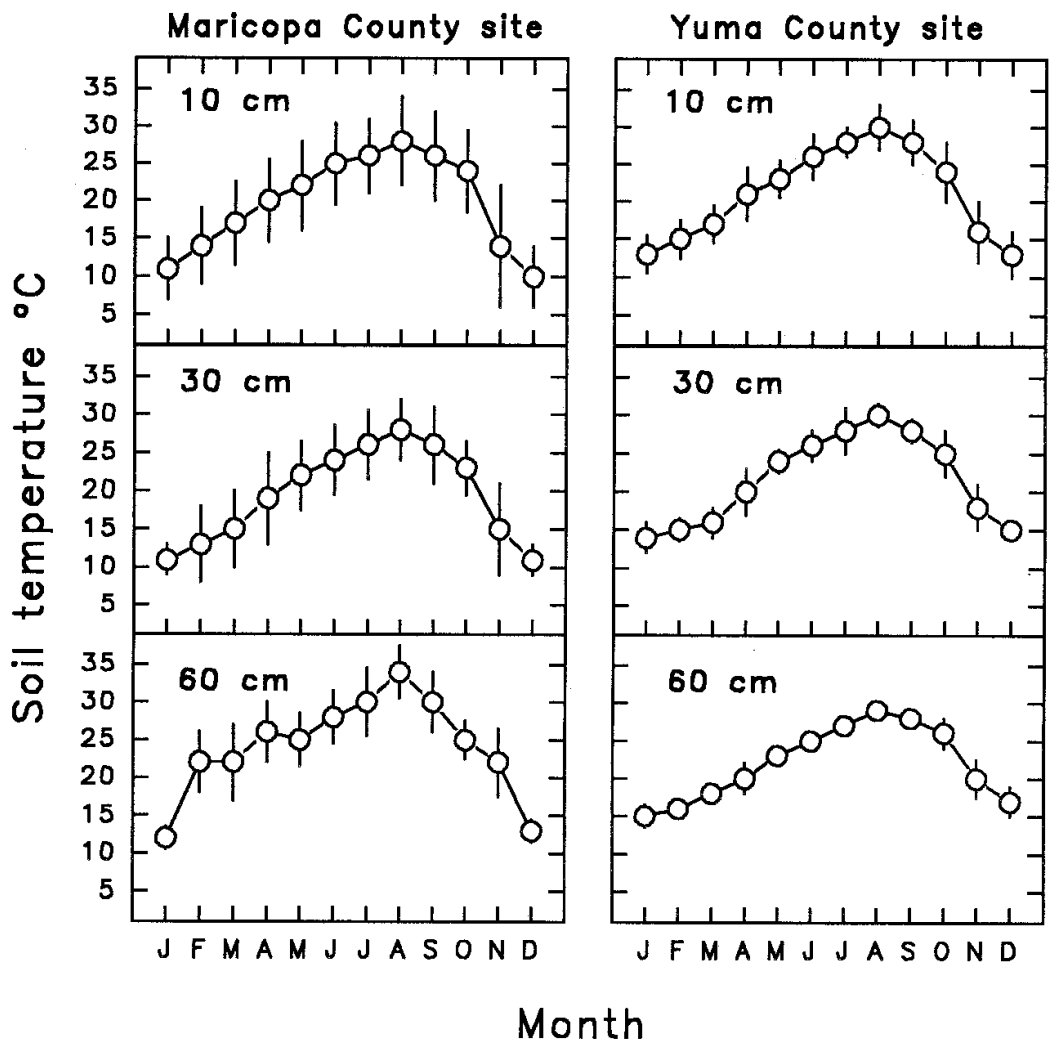

Fig. 2. The average monthly soil temperature recorded during 1992 at depths of 10, 30, and $60 \mathrm{~cm}$ within a navel orange orchard in Maricopa County and a Valencia orange orchard in Yuma County. Vertical bars indicate the range of temperatures recorded during each month. for trees treated with fosetyl-Al or metalaxyl were significantly greater than those of untreated trees.

\section{DISCUSSION}

$P$. citrophthora and $P$. parasitica, causal agents of gummosis and root rot, are widely distributed within citrus orchards in Arizona. A similar situation exists in California, where both fungi are considered important pathogens of citrus trees $(5,12)$. In contrast, $P$. parasitica alone is the main pathogen species in Florida and Texas $(27,28,31)$. In both Maricopa and Yuma Counties, where the majority of commercial citrus plantings are located in Arizona, more orchards were infested with $P$. parasitica than with $P$. citrophthora. Additionally, several orchards contained both pathogens.

A requirement for efficient use of fungicides to manage Phytophthora gummosis and root rot is to have these materials in place when disease development is likely to occur. One factor governing disease development is temperature. Earlier research demonstrated that substantial colonization of rootlets of rough lemon by $P$. citrophthora and $P$. parasitica occurred from 9 to 24 and 12 to $30^{\circ} \mathrm{C}$, respectively (20), while maximum development of bark lesions on rough lemon by each pathogen was recorded from 10 to 20 and 15 to $25^{\circ} \mathrm{C}$, respectively (17). The presence of both pathogens within an orchard, each with different temperature ranges favorable for initiation of disease, creates a broader range of temperatures and a corresponding longer time interval each year during which disease development must be suppressed.

An accurate and reproducible estimate of population density of Phytophthora spp. within citrus orchards is essential for determining if and when to implement a chemical disease management program. The multiple-year assessment of propagule densities for $P$. parasitica in the Yuma Mesa citrus production region revealed an overall population density of 16.7 propagules of $P$. parasitica/g of dry soil derived from 765 soil samples, indicating a sufficiently high population of the pathogen to

Table 5. Effect of fosetyl-Al or metalaxyl on health of tree canopy, root density, and propagule density of Phytophthora citrophthora and P. parasitica in a mature navel orange orchard on rough lemon rootstock ${ }^{u}$

\begin{tabular}{|c|c|c|c|c|c|c|c|c|c|}
\hline \multirow[b]{3}{*}{ Treatment } & \multirow{2}{*}{\multicolumn{3}{|c|}{ Canopy rating ${ }^{v}$}} & \multirow{2}{*}{\multicolumn{2}{|c|}{ Root density ${ }^{w}$}} & \multicolumn{4}{|c|}{ Population $^{x}$} \\
\hline & & & & & & \multicolumn{2}{|c|}{ P. citrophthora } & \multicolumn{2}{|c|}{ P. parasitica } \\
\hline & $6 / 88^{y}$ & $3 / 91$ & $3 / 92$ & $4 / 92$ & $11 / 92$ & $4 / 92$ & $11 / 92$ & $4 / 92$ & $11 / 92$ \\
\hline Nontreated & $2.1 \mathrm{a}^{\mathrm{z}}$ & $2.9 \mathrm{~b}$ & $3.0 \mathrm{~b}$ & $0.08 \mathrm{a}$ & $0.04 \mathrm{a}$ & $1.3 \mathrm{a}$ & $0 \mathrm{a}$ & $8.4 \mathrm{ab}$ & $5.8 \mathrm{a}$ \\
\hline Fosetyl-Al & $2.2 \mathrm{a}$ & $2.1 \mathrm{a}$ & $2.0 \mathrm{a}$ & $0.24 \mathrm{c}$ & $0.28 \mathrm{~b}$ & $3.7 \mathrm{a}$ & $0.2 \mathrm{a}$ & $8.8 \mathrm{a}$ & $4.9 \mathrm{a}$ \\
\hline Metalaxyl & $1.8 \mathrm{a}$ & $1.9 \mathrm{a}$ & $1.9 \mathrm{a}$ & $0.68 \mathrm{~b}$ & $0.32 \mathrm{~b}$ & $5.6 \mathrm{a}$ & $0.2 \mathrm{a}$ & $1.9 \mathrm{~b}$ & $2.1 \mathrm{a}$ \\
\hline
\end{tabular}

u Each number represents the average value from the 20 trees within each treatment.

${ }^{v}$ Canopy rating scale: $1=$ healthy tree; $2=$ some decline; $3=$ moderate decline; $4=$ severe decline; $5=$ dead tree.

${ }^{w}$ Density in mg dry weight of roots per $\mathrm{cm}^{3}$ of soil.

${ }^{x}$ Propagules of Phytophthora spp./g of dry soil. One g of dry soil is equivalent to $0.77 \mathrm{~cm}^{3}$.

y Date of sample collection.

${ }^{\mathrm{z}}$ Values in each column followed by a different letter are significantly different $(P<0.05)$ according to the Student-Newman-Keuls test. 
warrant initiation of a chemical disease management program $(22,30)$. On closer analysis of the data, however, $58 \%$ of soil samples contained 10 or less propagules of $P$. parasitica/g of soil, levels of the pathogen that likely cannot be treated economically with fosetyl-Al or metalaxyl $(22,30)$. Determination of population levels of Phytophthora spp. at several locations within a citrus planting could assist growers in distinguishing between portions of the orchard that could benefit from treatment with fungicides, and those where treatment would not be economically justified.

A reliable determination of population levels of Phytophthora spp. requires relatively consistent and reproducible quantification of pathogen levels at the time of sample collection and processing. Lutz and Menge (14) showed that the number of propagules of $P$. parasitica recovered from a citrus orchard was significantly higher 1 to 3 days after a furrow irrigation, as compared to 4 to 11 days after irrigation. Since the number of propagules 4 to 11 days after irrigation did not differ significantly in their study, we routinely collected soil samples at least 4 days after an irrigation or significant rainfall.

Seasonal fluctuations in propagule densities of $P$. parasitica, as described in California (6) and Italy (8), ranged from high levels during summer and early autumn to very low levels in winter, suggesting that population densities of this pathogen should not be measured from soil samples collected during the winter. In contrast, our findings as well as data from Florida (33) show that propagule densities of $P$. parasitica were not affected by the time of year that soil samples were collected and processed. A possible explanation for this discrepancy may involve the temperature of soil samples at the time of collection, during storage, and during the incubation period with agar media. Feld et al. (6) in California and Ippolito (8) in Italy both reported orchard soil temperatures of $10^{\circ} \mathrm{C}$ or less when soil samples were collected from November through January. Additionally, Ippolito incubated soil plates at $19^{\circ} \mathrm{C}$. When soil was collected in late winter in Florida, stored at $8^{\circ} \mathrm{C}$, then incubated at $20^{\circ} \mathrm{C}$ in agar media, no propagules of $P$. parasitica were detected (32). However, if soil collected in Florida was stored at $8^{\circ} \mathrm{C}$, then placed at $28^{\circ} \mathrm{C}$ for the remainder of the experiment, the number of detected propagules increased. Also, compared to soil maintained at $9^{\circ} \mathrm{C}$, Lutz et al. (15) in California found that temperatures between 12 and $34^{\circ} \mathrm{C}$ and lengthened incubation time increased recovery of propagules of $P$. parasitica from soil. In our study, average soil temperatures at the time of collection during the winter were never below $10^{\circ} \mathrm{C}$. Also, all soil samples collected in our studies were maintained at 21 to $25^{\circ} \mathrm{C}$ after collection and until process- ing, after which soil plates were incubated at $28^{\circ} \mathrm{C}$.

The population density of $P$. citrophthora recorded in a citrus orchard in Italy (8) was highest during May and June. Our data indicated a similar seasonal fluctuation in population density of this pathogen for 2 out of 3 years in one citrus orchard (Fig. 1), as well as a significantly higher population of $P$. citrophthora in April when compared to November of the same year in another orchard (Table 5). The cause of the observed seasonal fluctuation in population density of $P$. citrophthora is unclear. Perhaps, in a manner similar to the effect of low soil temperatures on dormancy of $P$. parasitica (13), high soil temperatures recorded during the summer are sufficient to induce dormancy in propagules of $P$. citrophthora. In earlier investigations, we found that colonization of citrus rootlets did not occur at or above $28^{\circ} \mathrm{C}(20)$. Soil temperatures at these levels were recorded routinely during the summer in orchards in Arizona where populations of $P$. citrophthora were measured (Fig. 2). Knowledge of seasonal changes in detectable population levels of $P$. citrophthora could be valuable when attempting to determine economic treatment thresholds for this pathogen in citrus orchards.

The length of the winter dormant period for citrus trees is related to the air temperature during the winter months (26). According to Cooper and Peynado (1), an increase in the number of days during the winter in which the daily air temperature fell below $10^{\circ} \mathrm{C}$ induced greater citrus tree dormancy and maintained it for a longer period of time. An earlier study (19) demonstrated a significant inverse linear relationship between the number of days in December and January with a mean air temperature below $10^{\circ} \mathrm{C}$, and the length of lesions that developed on excised citrus roots inoculated with $P$. citrophthora and $P$. parasitica. In the current study involving measurement of seasonal population densities of these 2 pathogens in a Maricopa County citrus orchard, the number of days during December and January with a mean air temperature below $10^{\circ} \mathrm{C}$ was 19,19 , and 34 for 1991 to 1992,1992 to 1993 , and 1993 to 1994, respectively. The greater state of dormancy presumably induced in the trees during 1993 to 1994 possibly is related to the observed decreases in population of $P$. citrophthora during the winter, spring, and summer of 1994 compared to these seasons in the previous 2 years.

In Florida, root densities in sweet orange orchards on sour orange and sweet orange rootstocks decreased sharply as soil depth increased from 0 to 23 to 69 to $92 \mathrm{~cm}$ (32). Dhandar and Singh (3) also found a majority of feeder roots in the top $20 \mathrm{~cm}$ of soil around flood-irrigated grapefruit on $C$. karna rootstock. Our data are in general agreement with these earlier reports, ex- cept that we observed no decrease in feeder root density in the Yuma County Valencia orange orchard, which was on Superstition sand and flood-irrigated, as soil depth increased from 30 to $60 \mathrm{~cm}$. Depth of rooting for citrus trees may be affected by rootstock as well as the method of irrigation (24). According to Rodney et al. (24), for trees in Yuma, Arizona on Superstition sand receiving flood irrigation, the majority of roots of Valencia orange trees on $C$. macrophylla and Troyer citrange rootstock were found at a soil depth of 60 to $120 \mathrm{~cm}$ and 0 to $60 \mathrm{~cm}$, respectively. In the same study, root densities at a soil depth of 0 to $60 \mathrm{~cm}$ for Valencia orange trees on $C$. macrophylla that received sprinkler, basin, or trickle irrigation were equivalent to or higher than those recorded at 60 to $120 \mathrm{~cm}$. On the other hand, under all irrigation regimes, root density of trees on Troyer citrange always decreased as soil depth increased from 0 to $60 \mathrm{~cm}$ to 60 to $120 \mathrm{~cm}$ (24).

Applications of fosetyl-Al and metalaxyl have been highly effective as management tools for feeder root rot on young citrus trees in nurseries $(2,4,23)$. Our data suggests that multiple-year applications of either of these fungicides to a navel orange orchard at least 30 years old on rough lemon rootstock preserved the health of tree canopies and increased root densities compared to nontreated trees; however, propagule levels of $P$. citrophthora and $P$. parasitica were not affected. Similar investigations in Florida involving four citrus orchards affected with feeder root rot caused by $P$. parasitica revealed that multiple-year treatments with fosetyl-Al or metalaxyl resulted in reduced propagule densities of the pathogen, improved visual health of trees, and enhanced root densities; however, these responses were not consistent in all orchards tested (25). A possible explanation for our inability to detect significant reduction of propagules of Phytophthora spp. was our infrequent sampling of soil during this trial. A significant reduction in propagule densities of $P$. parasitica after multiple-year treatments with fosetyl-Al or metalaxyl in Florida (25) was detected by sampling orchard soil several times per year over a 4 -year period.

The identity, distribution and population dynamics of Phytophthora spp. in the desert production regions of Arizona are not entirely identical to any other state in the United States where citrus is grown commercially. However, wherever citrus is grown, the question of when to initiate chemical disease management strategies is difficult to resolve. Studies suggest that the initiation of a chemical disease management program in citrus orchards affected by Phytophthora spp. does not automatically lead to increased yield (25). Researchers have suggested $(22,25)$ that population levels in the range of 10 to 15 propagules $/ \mathrm{cm}^{3}$ and 15 to 20 propagules $/ \mathrm{g}$ 
of soil and above could economically justify the initiation of a chemical disease management program. Other important factors that may influence a management decision include the age of the orchard, rootstock, soil type, and method of irrigation.

\section{LITERATURE CITED}

1. Cooper, W. C., and Peynado, A. 1959. Winter temperature of three citrus areas as related to dormancy and freeze injury of citrus trees. Proc. Am. Soc. Hortic. Sci. 74:333-347.

2. Davis, R. M. 1982. Control of Phytophthora root and foot rot of citrus with the systemic fungicides metalaxyl and phosethyl aluminum. Plant Dis. 66:218-220.

3. Dhandar, D. G., and Singh, R. 1989. Root studies in grapefruit (C. Paradisi Macf.) using radiotracer technique. Sci. Hortic. Amst. 40:113-118.

4. Farih, A., Menge, J. A., Tsao, P. H., and Ohr, H. D. 1981. Metalaxyl and efosite aluminum for control of Phytophthora gummosis and root rot on citrus. Plant Dis. 65:654-657.

5. Fawcett, H. S. 1936. Citrus Diseases and Their Control. McGraw-Hill, New York.

6. Feld, S. J., Menge, J. A., and Stolzy, L. H. 1990. Influence of drip and furrow irrigation on Phytophthora root rot of citrus under field and greenhouse conditions. Plant Dis. 74:2127.

7. Glantz, S. A. 1992. Primer of Biostatistics. 3rd ed. McGraw-Hill Book Co., New York.

8. Ippolito, A., DeCicco, V., and Salerno, M. 1992. Seasonal variation in root infections and population levels of Phytophthora spp. in citrus orchards of Apulia and Basilicata, Italy. Riv. Patol. Veg. 2:57-65.

9. Jeffers, S. N., and Martin, S. B. 1986. Comparison of two media selective for Phytophthora and Pythium species. Plant Dis. 70:1038-1043

10. Kannwischer, M. E., and Mitchell, D. J. 1978. The influence of a fungicide on the epidemiology of black shank of tobacco. Phytopathology 68:1760-1765.

11. Klotz, L. J. 1978. Fungal, bacterial, and nonparasitic diseases and injuries originating in the seedbed, and nursery orchard. Pages 1-66 in: The Citrus Industry. Vol. 4, Crop Protection. W. Reuther, E. C. Calavan, and G. F. Carman, eds. University of California Agricultural Sciences Publications, Richmond.
12. Klotz, L. J., DeWolfe, T. A., and Wong, P.-P. 1958. Decay of fibrous roots of citrus. Phytopathology 48:616-622.

13. Lutz, A., and Menge, J. 1986. Breaking winter dormancy of Phytophthora parasitica propagules using heat shock. Mycologia 78:148-150.

14. Lutz, A. L., and Menge, J. A. 1991. Population fluctuations and the numbers and types of propagules of Phytophthora parasitica that occur in irrigated citrus groves. Plant Dis. 75:173-179.

15. Lutz, A. L., Menge, J. A., and Ferrin, D. M. 1991. Increased germination of propagules of Phytophthora parasitica by heating citrus soils sampled during winter. Phytopathology 81:865-872.

16. Matheron, M. E., and Matejka, J. C. 1988. Persistence of systemic activity for fungicides applied to citrus trunks to control Phytophthora gummosis. Plant Dis. 72:170-174.

17. Matheron, M. E., and Matejka, J. C. 1992. Effects of temperature on sporulation and growth of Phytophthora citrophthora and $P$. parasitica and development of foot rot on citrus. Plant Dis. 76:1103-1109.

18. Matheron, M. E., and Matejka, J. C. 1993. Relationship of seasonal changes in soil temperature, sampling depth and root density to population of Phytophthora citrophthora and $P$. parasitica within Arizona citrus groves. Page 281 in: Abstracts of the Sixth International Congress of Plant Pathology, Montreal, Canada.

19. Matheron, M. E., and Matejka, J. C. 1993. Seasonal differences in susceptibility of three citrus rootstocks to root lesions caused by Phytophthora citrophthora and P. parasitica. Plant Dis. 77:729-732.

20. Matheron, M. E., and Porchas, M. 1996. Colonization of citrus roots by Phytophthora citrophthora and P. parasitica in daily soil temperature fluctuations between favorable and inhibitory levels. Plant Dis. 80:11351140 .

21. Matheron, M. E., Young, D. J., and Matejka, J. C. 1988. Phytophthora root and crown rot of apple trees in Arizona. Plant Dis. 72:481-484.

22. Menge, J. A. 1986. Use of systemic fungicides on citrus. Citrograph 71(12):245-252.

23. Ohr, H. D., Murphy, M. K., and Bender, G. 1986. Control of Phytophthora root rot in container-grown citrus. Calif. Agric. 40(56):18-19.
24. Rodney, D. R., Roth, R. L., and Gardner, B R. 1977. Citrus responses to irrigation methods. Proc. Int. Soc. Citric. 1:106-110.

25. Sandler, H. A., Timmer, L. W., Graham, J. H., and Zitko, S. E. 1989. Effect of fungicide applications on populations of Phytophthora parasitica on feeder root densities and fruit yields on citrus trees. Plant Dis. 73:902-906.

26. Sinclair, W. B. 1984. The Biochemistry and Physiology of the Lemon and Other Citrus Fruits. Publ. 3306. University of California Division of Agriculture and Natural Resources, Oakland.

27. Timmer, L. W. 1972. Management of soilborne diseases of citrus in the Lower Rio Grande Valley. J. Rio Grande Valley Hortic. Soc., 26:44-58

28. Timmer, L. W. 1973. Characteristics of Phytophthora isolates from Texas citrus orchards. J. Rio Grande Valley Hortic. Soc. 27:44-48.

29. Timmer, L. W., and Castle, W. S. 1985. Effectiveness of metalaxyl and fosetyl Al against Phytophthora parasitica on sweet orange. Plant Dis. 69:741-743.

30. Timmer, L. W., Graham, J. H., Sandler, H. A., and Zitko, S. E. 1988. Populations of Phytophthora parasitica in citrus orchards and tree response to fungicide applications. Citrus Ind. 69(11):40-44, 54

31. Timmer, L. W., Menge, J. A., Zitko, S. E. Pond, E., Miller, S. A., and Johnson, E. L. 1993. Comparison of ELISA techniques and standard isolation methods for Phytophthora detection in citrus orchards in Florida and California. Plant Dis. 77:791-796.

32. Timmer, L. W., Sandler, H. A., Graham, J. H., and Zitko, S. E. 1988. Sampling citrus orchards in Florida to estimate populations of Phytophthora parasitica. Phytopathology 78:940-944.

33. Timmer, L. W., Zitko, S. E., Sandler, H. A and Graham, J. H. 1989. Seasonal and spatial analysis of populations of Phytophthora parasitica in citrus orchards in Florida. Plant Dis. 73:810-813.

34. Tsao, P. H., and Guy, S. O. 1977. Inhibition of Mortierella and Pythium in a Phytophthoraisolation medium containing hymexazol. Phytopathology 67-796-801.

35. Tsao, P. H., and Ocana, G. 1969. Selective isolation of species of Phytophthora from natural soils on an improved antibiotic medium. Nature 223:636-638. 